\title{
Income Statement vs. Comprehensive Income Statement
}

\author{
Burcu Adiloglu \\ Istanbul University, School of Business, Turkey
}

\begin{abstract}
The objective of general purpose financial statements is to provide information about the financial position, financial performance, and cash flows of a company that is useful to a wide range of users in making economic decisions. In June 1997, the FASB issued FAS130 on how to report comprehensive income, so second type of income statement is came up. Under the traditional income concept-income statement, extraordinary and nonrecurring gains and losses are excluded from income. Under the all-inclusive income conceptcomprehensive income statement, all revenues, expenses, gains, and losses recognized during the period are included in income, regardless of whether they are considered to be operations of the period. International Accounting Standards Board (IASB) also introduced this issue in 2009. According to the standard a business entity using IFRS must also include a statement of comprehensive income. The aim of this study is to discuss the necessity and need for presentation of two performance statements- income comprehensive income- especially from the perspective from investors while these items are stated in equity section of the balance sheets. Effects of this dual reporting of income statements which leads confusion are also discussed by examining cases from different countries and survey is conducted to BIST (Borsa Istanbul) 30 companies from Turkey.
\end{abstract}

Keywords: Income statement, comprehensive income statement, net income, dual reporting case, Turkey

Jel Code: M 41

DOI: $10.7176 / \mathrm{EJBM} / 11-35-05$

Publication date: December $31^{\text {st }} 2019$

\section{Introduction}

In recent years, society as a whole, through governmental and public groups, has become one of the largest and most important users of accounting information. Users who need accounting information to make decisions on public issues include tax authorities, regulatory agencies, and various other groups. (Needles et al.,2013)

International Accounting Standard- IAS 1 Presentation of Financial Statements sets out the overall requirements for financial statements, including how they should be structured, the minimum requirements for their content. The objective of IAS 1 is to prescribe the basis for presentation of general purpose financial statements, to ensure comparability both with the entity's financial statements of previous periods and with the financial statements of other entities.

According to IAS 1 a complete set of financial statements includes:

- a statement of financial position (balance sheet) at the end of the period

- a statement of profit or loss and other comprehensive income for the period (presented as a single statement, or by presenting the profit or loss section in a separate statement of profit or loss, immediately followed by a statement presenting comprehensive income beginning with profit or loss)

- a statement of changes in equity for the period

- a statement of cash flows for the period

and notes, comprising a summary of significant accounting policies and other explanatory notes comparative information prescribed by the standard.

The paper is organized as follows. Section II briefly summarizes what is income statement and comprehensive income statement. Section III explains the data and methodology of the study and the results are presented in Section IV. Finally, Section V gives the conclusion.

\section{Income Statement and Comprehensive Income Statement}

As stated above companies have to prepare four financial statements according to IASB. One of them is income statement which summarizes the revenues earned and expenses incurred by a business over an accounting period. From the view of the investors it may be the most important financial report because it shows whether a business achieved its profitability goal - that is, whether it earned an acceptable income and whether it is worth to invest to this company. According to IAS 1 there are two types of income statement. A statement of profit or loss and other comprehensive income for the period (presented as a single statement, or by presenting the profit or loss section in a separate statement of profit or loss, immediately followed by a statement presenting comprehensive income beginning with profit or loss)

In June 1997, the Financial Accounting Standards Board (FASB) issued FAS130- "Reporting Comprehensive Income" in which comprehensive income concept came out. This is an extra income reporting and different from the traditional income statement. Under the traditional income concept-income statement, 
extraordinary and nonrecurring gains and losses are excluded from income. This is an all-inclusive income concept- comprehensive income statement, in which all revenues, expenses, gains, and losses recognized during the period are included in income, regardless of whether they are considered to be operations of the period. After FASB International Accounting Standards Board (IASB) also introduced this issue in 2009.

Profit or loss is defined as "the total of income less expenses, excluding the components of other comprehensive income". Other comprehensive income is defined as comprising "items of income and expense (including reclassification adjustments) that are not recognized in profit or loss as required or permitted by other IFRSs". Total comprehensive income is defined as "the change in equity during a period resulting from transactions and other events, other than those changes resulting from transactions with owners in their capacity as owners". (IAS 1.) In order to calculate comprehensive income, for the period other comprehensive income items must be added to profit or loss of the period.

\begin{tabular}{|lll}
$\begin{array}{l}\text { Comprehensive } \\
\text { for the period }\end{array}$ & income $=$ & $\begin{array}{l}\text { Profit } \\
\text { or loss }\end{array}$
\end{tabular}$\quad+\quad \begin{aligned} & \text { Other } \\
& \text { comprehensive income }\end{aligned}$

Examples of items recognized outside of profit or loss (IAS 1)

- Changes in revaluation surplus where the revaluation method is used under IAS 16 Property, Plant and Equipment and IAS 38 Intangible Assets

- Remeasurements of a net defined benefit liability or asset recognized in accordance with IAS 19 Employee Benefits (2011)

- Exchange differences from translating functional currencies into presentation currency in accordance with IAS 21 The Effects of Changes in Foreign Exchange Rates

- Gains and losses on remeasuring available-for-sale financial assets in accordance with IAS 39 Financial Instruments: Recognition and Measurement

- The effective portion of gains and losses on hedging instruments in a cash flow hedge under IAS 39 or IFRS 9 Financial Instruments

- Gains and losses on remeasuring an investment in equity instruments where the entity has elected to present them in other comprehensive income in accordance with IFRS 9

- The effects of changes in the credit risk of a financial liability designated as at fair value through profit and loss under IFRS 9.

An entity has a choice of presenting:

- a single statement of profit or loss and other comprehensive income, with profit or loss and other comprehensive income presented in two sections, or

- two statements:

- a separate statement of profit or loss

- a statement of comprehensive income, immediately following the statement of profit or loss and beginning with profit or loss [IAS 1.10A]

The statement(s) must present: [IAS 1.81A]

- $\quad$ profit or loss

- total other comprehensive income

- comprehensive income for the period

Under the revised presentation requirements including comprehensive income information Bank of America showed comprehensive income figures on either the face of the income statement or in a separate consecutive statement as follows, as it seen from the example there are two income data. (Peters, 2012)

(Dollars in Millions)

12/31/11

EPS 12/31/10 EPS

Net income (Loss)

$\$ 1,446 \quad \$ .01 \quad \$(2,238) \quad \$(.37)$

Other Comprehensive Income:

Cumulative change in accounting principle

Net change in securities

Net change in derivatives

Employee benefit plan adjustments

Net change in foreign currency translation

Total Other Comprehensive Income

\section{Comprehensive Income (Loss)}

\begin{tabular}{|c|c|c|}
\hline$(5,371)$ & & $\$ 5,440$ \\
\hline$\$(3,925)$ & $\$(.52)$ & $\$ 3,315$ \\
\hline
\end{tabular}

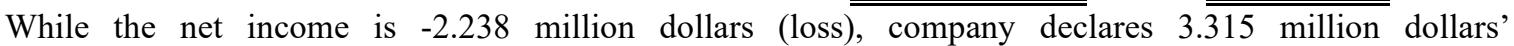
comprehensive income for the year 2010. In this statement there are two income figures. For an investor which 
income data will be taken in economic decisions is a very important issue.

Here is another example is given below which represents the dual income reporting difference. If company has material other comprehensive income or loss for the period, then there may be huge difference between these two income figures.

The related information is summarized below. As of December,31,2016 company declares -47.000 .000$ Turkish Liras (TL) net income (loss) and because of the huge other comprehensive income items, the total compressive income is $-8204 \%$ percent of the net income information. (3.809.000.000 TL)

\begin{tabular}{|c|l|r|l|r|}
\hline & $\begin{array}{l}\text { Comprehensive } \\
\text { Income } \\
\text { Net Income (31.12.2016) }\end{array}$ & $\begin{array}{l}\text { Net Income } \\
\mathbf{3 1 . 1 2 . 2 0 1 6 )}\end{array}$ & $\begin{array}{l}\text { Comprehensive } \\
\text { Income } \\
\mathbf{3 1 . 1 2 . 2 0 1 6}\end{array}$ & $\begin{array}{l}\text { Difference } \\
\text { percentage }\end{array}$ \\
\hline $\mathbf{- 4 7 . 0 0 0 . 0 0 0}$ & $\mathbf{3 . 8 0 9 . 0 0 0 . 0 0 0}$ & $\mathbf{1 0 0}$ & $\mathbf{- 8 1 0 4}$ & $\mathbf{- 8 2 0 4 \%}$ \\
\hline
\end{tabular}

TŨRK HAVA YOL.L.ARI ANONIM ORTAKLIĞI AND ITS SUBSIDIARIES

Consolidated Statement of Profit or Loss and Other Comprehensive Ineome

For the Year Ended 31 December 2016

(All amousts are espressed in Millies Turkish Lira (TRY) wakss othersise stated.)

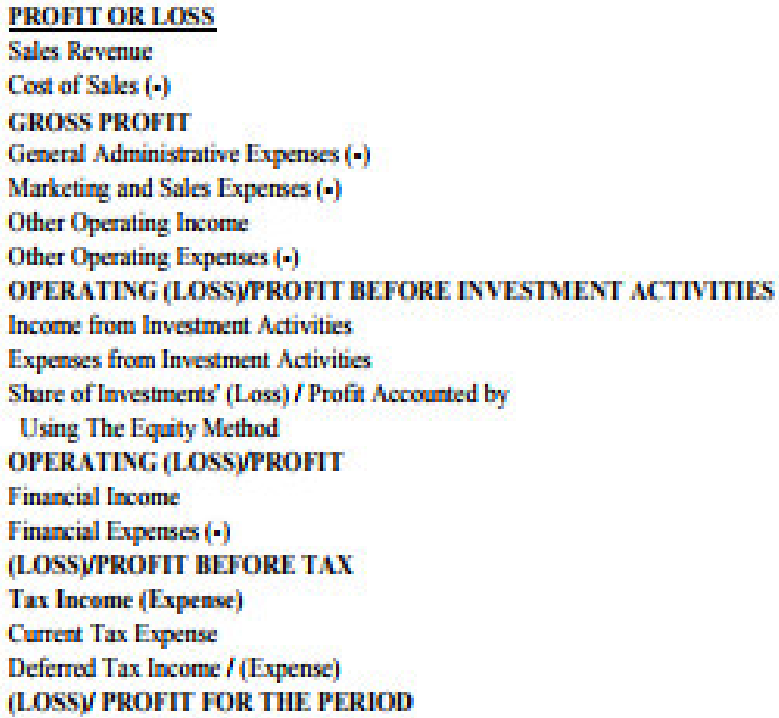

\section{OTHER COMPREHENSWV INCOME}

Items That May Be Reclassified Subsequently To Profit or Loss

Currency Translation Adjustment

Fair Valbe Gains on Hedging Instruments Entered into for

Cash Flow Hedges

Fair Value Gairs A Losses) Hedging Instruments of Investment Acoounted by

Using the Equity Method Enkered iato for Canh Flow Hedges

Income Tax Relating ltems That May Be Reclassified

Subsequently to Profit or Loss

Items That Will Not Be Reclassified

Subrequently To Profit or Less

Actuarial Gains on Retirement Pay Obligation

Income Tax Relating ltems That Will Not Be

Reclassified Subsequently to Profit or Loss

OTIIER COMPREHENSIVE. INCOME FOR THE PE.RIOD

TOTAL COMPREIENSIVE (EXPENSE) /INCOME FOR THE PERIOD
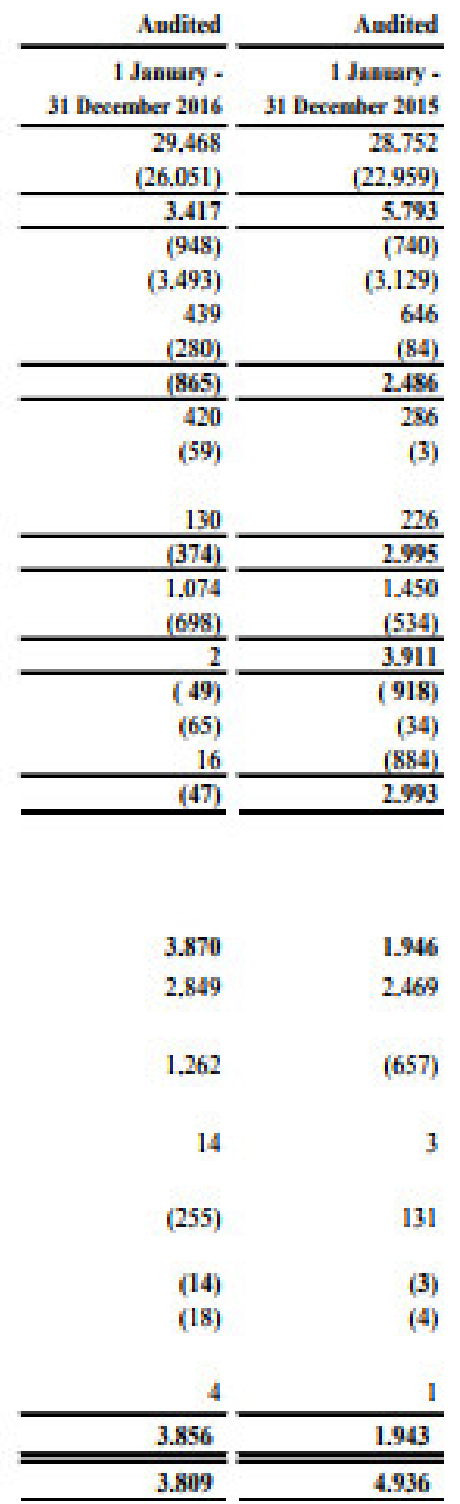

\section{Data Set and Methodology}

The data for the study is obtained from Borsa Istanbul (http:/www.borsaistanbul.com) which contains accounting and finance information of publicly-opened firms listed in Borsa Istanbul (BIST)- Istanbul Stock Exchange. The data set includes firms listing in ISE 30 Indices as of December 31,2016 and the study is restricted for two years; 2015 and 2016. BIST30 consists of the largest and most liquid shares of leading 30 
public companies. Because financial statements of one company lack of information, 29 firms are included in the study.

The aim of the study is to investigate and see the difference of this dual income reporting of first 29 companies in Istanbul Stock Exchange.

The distribution of types of companies in this study are categorized as financial or nonfinancial are shown in Table 1, Table 2.

Table 1: The Data

\begin{tabular}{|c|c|c|}
\hline NAME OF THE COMPANY & FINANCIAL/NONFINANCIAL & SINGLE OR TWO STATEMENTS \\
\hline AKBANK & Financial & Two Statements \\
\hline GARANTI BANKASI & Financial & Two Statements \\
\hline SISE CAM & Nonfinancial & Two Statements \\
\hline IS BANKASI & Financial & Two Statements \\
\hline TOFAS OTO. FAB. & Nonfinancial & Two Statements \\
\hline VAKIFLAR BANKASI & Financial & Two Statements \\
\hline TURKCELL & Nonfinancial & Two Statements \\
\hline KOC HOLDING & Nonfinancial & Two Statements \\
\hline PETKIM & Nonfinancial & Single \\
\hline ARCELIK & Nonfinancial & Two Statements \\
\hline KARDEMIR & Nonfinancial & Single \\
\hline ENKA INSAAT & Nonfinancial & Two Statements \\
\hline BIM MAGAZALAR & Nonfinancial & Single \\
\hline SABANCI HOLDING & Nonfinancial & Two Statements \\
\hline SODA SANAYII & Nonfinancial & Two Statements \\
\hline T. HALK BANKASI & Financial & Two Statements \\
\hline TAV HAVALIMANLARI & Nonfinancial & Single \\
\hline TUPRAS & Nonfinancial & Single \\
\hline TEKFEN HOLDING & Nonfinancial & Two Statements \\
\hline TURK TELEKOM & Nonfinancial & Two Statements \\
\hline MAVI GIYIM & Nonfinancial & Single \\
\hline ASELSAN & Nonfinancial & Two Statements \\
\hline DOGAN HOLDING & Nonfinancial & Two Statements \\
\hline YAPI VE KREDI BANK. & Financial & Two Statements \\
\hline EREGLI DEMIR CELIK & Nonfinancial & Two Statements \\
\hline EMLAK KONUT GMYO & Financial & Single \\
\hline OTOKAR & Nonfinancial & Single \\
\hline ULKER BISKUVI & Nonfinancial & Two Statements \\
\hline TURK HAVA YOLLARI & Nonfinancial & Single \\
\hline
\end{tabular}

According the data that is investigated in this study $24 \%$ of 29 companies are financial and $76 \%$ of them is nonfinancial company.

Table 2: Types of Companies

\begin{tabular}{|l|l|l|}
\hline Type & Number of companies & Percentage \\
\hline Financial & 7 & $24 \%$ \\
\hline Nonfinancial & 22 & $76 \%$ \\
\hline Total & $\mathbf{2 9}$ & $\mathbf{1 0 0 \%}$ \\
\hline
\end{tabular}

According to IAS 1 companies can prepare single income statement which includes comprehensive income information or two separate income statements. (a statement of profit or loss and other comprehensive income for the period (presented as a single statement, or by presenting the profit or loss section in a separate statement of profit or loss, immediately followed by a statement presenting comprehensive income beginning with profit or loss). In this study this information is also investigated. The results presented in Table 3.

Table 3: Presentation Style

\begin{tabular}{|l|l|l|}
\hline Presentation Type & Number of companies & Percentage \\
\hline Single & 9 & $31 \%$ \\
\hline Two statements & 20 & $69 \%$ \\
\hline Total & $\mathbf{2 9}$ & $\mathbf{1 0 0 \%}$ \\
\hline
\end{tabular}




\section{Findings of The Study}

In this study the data set includes firms listing in ISE 30 indices as of December 31,2016 and the study is restricted for two years; 2015 and 2016. Since the financial statements of one company lack of information, available information of 29 companies is considered in the study. The aim of the study is to compare net income and the comprehensive income figures of these companies for the years 2015 and 2016.

In this study the net income information is for each company is represented as 100 and comprehensive income is calculated as a percentage of net income. This logic is conducted to each company and to each year (2015 and 2016) separately in order to see how these figures differ from each other.

Table 4: Findings for the year 2015

\begin{tabular}{|c|c|c|c|c|c|}
\hline Name of the Company & $\begin{array}{l}\text { Net Income } \\
(31.12 .2015)\end{array}$ & \begin{tabular}{|l|} 
Comprehensive \\
Income \\
$(\mathbf{3 1 . 1 2 . 2 0 1 5 )}$ \\
\end{tabular} & $\begin{array}{l}\text { Net Income } \\
(31.12 .2015)\end{array}$ & $\begin{array}{l}\text { Comprehensive } \\
\text { Income } \\
(\mathbf{3 1 . 1 2 . 2 0 1 5 )} \\
\end{array}$ & $\begin{array}{l}\text { Difference } \\
\text { as } \\
\text { percentage }\end{array}$ \\
\hline AKBANK & 3.229 .366 .000 & 2.444 .437 .000 & 100 & 76 & 0 \\
\hline GARANTI BANKASI & 3.615 .114 .000 & 5.111 .095 .000 & 100 & 141 & 0 \\
\hline SISE CAM & 804.866 .447 & 2.495 .685 .981 & 100 & 310 & $210 \%$ \\
\hline IS BANKASI & 3.739 .671 .000 & 3.870 .877 .000 & 100 & 104 & $4 \%$ \\
\hline TOFAS OTO. FAB. & 830.801 .000 & 825.666 .000 & 100 & 99 & $-1 \%$ \\
\hline VAKIFLAR BANKASI & 1.873 .913 .000 & 2.143 .745 .000 & 100 & 114 & $14 \%$ \\
\hline TURKCELL & 1.905 .790 .000 & 1.505 .391 .000 & 100 & 79 & $-21 \%$ \\
\hline KOC HOLDING & 5.829 .351 .000 & 5.336 .265 .000 & 100 & 92 & $-8 \%$ \\
\hline PETKIM & 639.208 .658 & 622.122 .630 & 100 & 97 & $-3 \%$ \\
\hline ARCELIK & 892.993 .000 & 847.240 .000 & 100 & 95 & $-5 \%$ \\
\hline KARDEMIR & 21.436 .461 & 874.724 .661 & 100 & -4081 & $-4181 \%$ \\
\hline ENKA INSAAT & 1.455 .501 .000 & 2.305 .044 .000 & 100 & 158 & $58 \%$ \\
\hline BIM MAGAZALAR & 583.131 .000 & 789.827 .000 & 100 & 135 & $35 \%$ \\
\hline SABANCI HOLDING & 4.421 .082 .000 & 3.722 .965 .000 & 100 & 84 & $-16 \%$ \\
\hline SODA SANAYII & 441.073 .019 & 678.149 .796 & 100 & 154 & $54 \%$ \\
\hline T. HALK BANKASI & 2.328 .310 .000 & 3.572 .819 .000 & 100 & 153 & $53 \%$ \\
\hline TAV HAVALIMANLARI & 604.732 .000 & 928.064 .000 & 100 & 153 & $53 \%$ \\
\hline TUPRAS & 2.563 .927 .000 & 2.094 .706 .000 & 100 & 82 & $-18 \%$ \\
\hline TEKFEN HOLDING & 193.036 .000 & 123.321 .000 & 100 & 64 & $-36 \%$ \\
\hline TURK TELEKOM & 862.850 .000 & 723.759 .000 & 100 & 84 & $-16 \%$ \\
\hline MAVI GIYIM & 33.452 .943 & 33.975 .733 & 100 & 102 & $2 \%$ \\
\hline ASELSAN & 213.373 .000 & 366.579 .000 & 100 & 172 & $72 \%$ \\
\hline DOGAN HOLDING & 172.994 .000 & 138.490 .000 & 100 & 80 & $-20 \%$ \\
\hline YAPI VE KREDI BANK. & 1.908 .728 .000 & 3.272 .738 .000 & 100 & 171 & $71 \%$ \\
\hline EREGLI DEMIR CELIK & 1.162 .309 .000 & 3.636 .990 .000 & 100 & 313 & $213 \%$ \\
\hline EMLAK KONUT GMYO & 952.605 .000 & 952.321 .000 & 100 & 100 & $0 \%$ \\
\hline OTOKAR & 79.506 .151 & 80.911 .723 & 100 & 102 & $2 \%$ \\
\hline ULKER BISKUVI & 322.814 .136 & 560.374 .932 & 100 & 174 & $74 \%$ \\
\hline TURK HAVA YOLLARI & 2.993 .000 .000 & 4.936 .000 .000 & 100 & 165 & $65 \%$ \\
\hline
\end{tabular}

Table 5: Findings for the year 2016

\begin{tabular}{|c|c|c|c|c|c|}
\hline Name of the Company & Net Income (31.12.2016) & $\begin{array}{l}\text { Comprehensive } \\
\text { Income } \\
(\mathbf{3 1 . 1 2 . 2 0 1 6 )} \\
\end{array}$ & \begin{tabular}{|l|} 
Net \\
Income \\
$\mathbf{3 1 . 1 2 . 2 0 1 6}$ \\
\end{tabular} & \begin{tabular}{|l|} 
Comprehensive \\
Income \\
$(\mathbf{3 1 . 1 2 . 2 0 1 6 )}$ \\
\end{tabular} & $\begin{array}{l}\text { Difference } \\
\text { as } \\
\text { percentage } \\
\end{array}$ \\
\hline AKBANK & 4.854 .179 .000 & 5.077 .376 .000 & 100 & 105 & $5 \%$ \\
\hline GARANTI BANKASI & 5.147 .759 .000 & 5.160 .361 .000 & 100 & 100 & $0 \%$ \\
\hline SISE CAM & 1.040 .028 .635 & 1.500 .989 .697 & 100 & 144 & $44 \%$ \\
\hline IS BANKASI & 5.682 .858 .000 & 5.325 .615 .000 & 100 & 94 & $-6 \%$ \\
\hline TOFAS OTO. FAB. & 970.228 .000 & 740.160 .000 & 100 & 76 & $-24 \%$ \\
\hline VAKIFLAR BANKASI & 2.792 .446 .000 & 2.709 .957 .000 & 100 & 97 & $-3 \%$ \\
\hline TURKCELL & 1.563 .451 .000 & 1.667 .076 .000 & 100 & 107 & $7 \%$ \\
\hline KOC HOLDING & 5.276 .386 .000 & 5.097 .897 .000 & 100 & 97 & $-3 \%$ \\
\hline PETKIM & 731.687 .346 & 736.556 .529 & 100 & 101 & $1 \%$ \\
\hline ARCELIK & 1.304 .150 .000 & 1.515 .617 .000 & 100 & 116 & $16 \%$ \\
\hline KARDEMIR & 123.877 .113 & 111.582 .956 & 100 & 90 & $-10 \%$ \\
\hline ENKA INSAAT & 1.809 .132 .000 & 4.435 .807 .000 & 100 & 245 & $145 \%$ \\
\hline BIM MAGAZALAR & 670.859 .000 & 625.452 .000 & 100 & 93 & $-7 \%$ \\
\hline
\end{tabular}




\begin{tabular}{|c|c|c|c|c|c|}
\hline Name of the Company & Net Income (31.12.2016) & \begin{tabular}{|l|} 
Comprehensive \\
Income \\
$(\mathbf{3 1 . 1 2 . 2 0 1 6 )}$ \\
\end{tabular} & \begin{tabular}{|l|} 
Net \\
Income \\
31.12.2016 \\
\end{tabular} & \begin{tabular}{|l|} 
Comprehensive \\
Income \\
$(\mathbf{3 1 . 1 2 . 2 0 1 6 )}$ \\
\end{tabular} & $\begin{array}{l}\text { Difference } \\
\text { as } \\
\text { percentage }\end{array}$ \\
\hline SABANCI HOLDING & 5.547 .146 .000 & 5.822 .517 .000 & 100 & 105 & $5 \%$ \\
\hline SODA SANAYII & 576.624 .415 & 667.419 .443 & 100 & 116 & $16 \%$ \\
\hline T. HALK BANKASI & 2.539 .456 .000 & 2.441 .448 .000 & 100 & 96 & $-4 \%$ \\
\hline TAV HAVALIMANLARI & 399.379 .000 & 782.497 .000 & 100 & 196 & $96 \%$ \\
\hline TUPRAS & 1.812 .790 .000 & 1.227 .971 .000 & 100 & 68 & $-32 \%$ \\
\hline TEKFEN HOLDING & 330.323 .000 & 367.499 .000 & 100 & 111 & $11 \%$ \\
\hline TURK TELEKOM & 724.340 .000 & 765.888 .000 & 100 & 106 & $6 \%$ \\
\hline MAVI GIYIM & 51.813 .223 & 51.998 .904 & 100 & 100 & $0 \%$ \\
\hline ASELSAN & 795.201 .000 & 892.731 .000 & 100 & 112 & $12 \%$ \\
\hline DOGAN HOLDING & 233.886 .000 & 20.090 .000 & 100 & 9 & $-91 \%$ \\
\hline YAPI VE KREDI BANK. & 2.932 .860 .000 & 3.034 .788 .000 & 100 & 103 & $3 \%$ \\
\hline EREGLI DEMIR CELIK & 1.571 .702 .000 & 4.171 .155 .000 & 100 & 265 & $165 \%$ \\
\hline EMLAK KONUT GMYO & 1.761 .276 .000 & 1.760 .866 .000 & 100 & 100 & $0 \%$ \\
\hline OTOKAR & 69.725 .866 & 69.990 .703 & 100 & 100 & $0 \%$ \\
\hline ULKER BISKUVI & 242.004 .730 & 381.331 .661 & 100 & 158 & $58 \%$ \\
\hline TURK HAVA YOLLARI & 47.000 .000 & 3.809 .000 .000 & 100 & -8104 & $-8204 \%$ \\
\hline
\end{tabular}

\section{Conclusion}

Sir Arthur Lowes Dickinson (8 August 1859 - 28 February 1935) was a British chartered accountant in England and the United States of America helped organize the First International Congress of Accountants in Saint Louis, Missouri, in this Congress in 1904 he delivered a paper entitled "Profits (Income) of a Corporation". After 100 years, todays, the accountants and accounting standard setters are still working on income and thinking about valuation and presentation styles.

From the perspective of the investors financial information especially net income information is very important and valuable in order to give the right economic decisions. In this dual reporting there are two income figures. For an investor which income data will be taken in economic decisions may be confusing. Since the main purpose of financial statements is giving information to decision makers, this information must be accurate and not lead to confusion. Although comprehensive income information is very important for an investor calculation of EPS (Earnings Per Share) is done by using net income figures. So that the most important figure for an investor is net income while the other (comprehensive income) is just informative. From this point of view presenting two separate income statement will be better informative than combined single income statement.

\section{References}

FASB, Statement of Financial Accounting Standards No. 130-FAS130 "Reporting Comprehensive Income”, June 1997.

IASB; International Accounting Standard- IAS 1, "Presentation of Financial Statements"

Borsa Istanbul, Retrieved from http://www.borsaistanbul.com

Needles, Belverd E., Marian Powers, and Susan V. Crosson.(2013) Principles of accounting. Cengage Learning.

Peters, Sandy, “Coming Soon to an Income Statement Near You: Comprehensive Income”, CFA Institute, 13 April 2012. 